\title{
Garrison state structure of Egypt and its implications for growth and development
}

\author{
Muhammad Ashar Khan, Hiba Shoaib, Fizza Fatima and Rimla Qamar \\ Social Development and Policy, School of Arts, Humanities and Social Sciences, \\ Habib University, Karachi, Pakistan \\ Email:amk04209@st.habib.edu.pk
}

\begin{abstract}
Ever since Egypt's independence in 1952, its military has enjoyed political leverage and patronage unparalleled to any other institution in the country. The domination of the military in the state's civil apparatus can be deemed as a key factor that has undermined Egypt's socio-economic growth and development. This paper, therefore, by employing Garrison State theory, formulated by Harold Laswell, aims to understand the ramifications of military domination on Egypt's political economy. While examining its impact on the country's macro-economy, the paper also examines the implication of military domination on Egypt's socio-economic indicators, namely: health, education, income, and gender equality. Structuring the analysis on Amartya Sen's schema of Development as Freedom, the paper concludes that diversification and democratization of the political structure are imperative to overcome the plight of underdevelopment in Egypt.
\end{abstract}

Keywords:Political Economy, Garrison State, Egypt, Military, Growth, Development, Freedom

\section{Introduction}

The political economy of Egypt has been increasingly marked with a lack of development, low economic growth, political instability, and high unemployment. Ever since its independence in 1952, the military has remained the dominant entity, which has enjoyed political leverage and patronage unparalleled to any other institution in the country. To this date, the Egypt Armed 
Forces (EAF) possess vast landholdings, and executive positions in government institutions and private businesses (Transparency International, 2018). The Supreme Council of the Armed Forces (SCAF) governs Egypt by exercising its control over the means of violence, which is why its power largely remains unchallenged by other institutions.

The influence of the military can be deemed as a prominent factor that has undermined Egypt's economic growth. This paper aims to examine the authoritarian role of the military in retaining control in Egypt, and how, by doing so, it has emerged as a ruling elite that has ruptured the socioeconomic climate of the country. Moreover, the paper examines the military's impact on education, health, and income - key indicators of human development - as well as gender inequality to indicate how the socio-economic growth in Egypt has been greatly curtailed by the military's authoritarian rule. Similarly, it also examines the impact of Egyptian Armed Forces (EAF) domination on Egypt's aggregate production, employment, defence trade and other macroeconomic indicators to present a dynamic case for the impact of military domination on Egypt's political economy.

The paper employs the theory of Garrison State, which was first outlined by the political scientist, Harold Laswell in 1941, as a qualitative methodological approach for understanding the ramifications of military domination in Egypt. Moreover, by scrutinizing the so-called development under the military rule, the paper will also utilize Amartya Sen's (1999) schema propounded in his path-breaking work "Development as Freedom". Through Sen's lens, we aim to examine the true socio-economic implications of military-led development, and how it has limited, what Sen calls "freedom", of a common Egyptian.

Conceptual framework: the political economy of Garrison States Harold Laswell (1941) argued that garrison states emerge when military officers rise up the power ladder as the ruling elite and subsequently achieve expertise in the management of civilian affairs. Similarly, the military elite constitutes the helm of decision making and is responsible for setting the state's economic direction (Laswell, 1941). Such states become increasingly dictatorial, governmentalised, centralised, and integrated, as the military acquires the lion-share of the country's national resources. Thus, by exercising their control as the "specialist on violence", the military morphs into an aristocratic class in such states. Furthermore, Laswell argued that to provide legitimacy to their rule, the military of Garrison States foster expansion of the middle and upper-middle class that forms their civilian support base, exacerbating class 
inequality. However, political, and economic decisions remain the sole prerogative of the military elite (Laswell, 1941).

To legitimise their domination, the armed elite often argue that by employing technocratic methodologies and by taking decisions that are, ostensibly, in the greater interest of the population, they tend to safeguard the citizenry from threats that cannot be dealt with by the civilian state apparatus. However, numerous studies show that direct or indirect intervention of the military in state's decision making can halt economic growth and development because of the conflict of interest between the civil institutions and the armed forces (Birchler, 2012). This is because of the reason that investing in public goods that promote economic growth with a balanced dispersion of wealth throughout the population strata acts as a disincentive to the interests of the small military elite. Moreover, such states also limit political freedom of civil society to curb opposition; thus, decisions made by the military elite largely remain unchallenged, which further undermines economic freedom and liberalisation, slowing down the pace of economic growth.

Problems of misallocation of public resources, corruption, nepotism, unemployment, and unequal distribution of wealth are, therefore, prevalent in garrison-state economies. This makes the macroeconomic structure of such states unsustainable and prone to public revolt. Consequently, such states also employ state resources to accumulate massive internal defence expenditures to curb public dissent, which further adds burden on the already encumbered economic growth (Deger \& Smith, 1983; Collier, 2006). Furthermore, even if resources are directed towards military research and development (R\&D), the cost and distortion of public capital are often counterproductive in economic and social terms (Buzan \& Sen, 1990). Similarly, excessive military expenditure and diversion of public resources to the military apparatus can also exacerbate income inequality eliciting further instability (Abell, 1994). Likewise, militarydominated economies of the developing world also tend to accumulate massive trade-deficits, because of high expenditure on defence imports. Such factors, thus, not only undermine economic growth but also place a significant toll on a country's debt and current account.

Our analysis shows that Egypt exhibits a number of such characteristics - typical to a garrison state. Building on this idea, we argue that such characteristics define the current economic structure of Egypt, which is increasingly becoming unsustainable. Moreover, although the macroeconomic indicators of Egypt, even after the COVID-19 pandemic induced global recession, paints a satisfying picture of the country's economy, they ignore the deep structural issues that 
can undermine long-term economic growth in the country. Similarly, they also fail to capture the socio-economic implication of military domination, which can further lead to erroneous and misleading convictions about the country's development.

Political climate: historical evolution of Egypt's Garrison State

Gamal Abdel Nasser (1956-1970)

Nasser's presidency was dominated by the military, while the freedom of civil society was greatly curtailed. He banned political parties and labour unions, restricting the formation of NGOs and other civil right groups. In view of the Egyptian sociologist, Saad Eddin Ibrahim, the development of civil society under Nasser was not relevant to the progress of democratization. Ibrahim notes that a functional civil society is defined as "non-state actors, and non-governmental organizations, such [as] political parties, trade unions, professional organizations and other interest groups" (Ibrahim, 2005). However, a quasi-autonomous civil society that emerged under Nasser's rule was nothing but a tool to strengthen his autocratic leadership and socialist agenda. Those who rallied behind him received perks of supporting the central command, while those who criticized his government were detained or banished out of Egypt. Meanwhile, the army base expanded as civilians were pushed to the peripheries of the government structure.

Nevertheless, senior officers took the positions of ministers, and the Pan-Arabism social and political ideology of having the strongest military in the region was used to accelerate its growth and expansion. The newly independent country went through a process of modernization under Nasser's regime, with the state using over $\$ 216 \mathrm{~m}$ to expand the EAF (Ahmed, 2017). Most of the resources were drawn towards the military, leading to military-owned manufacturing and development projects. Consequently, it gave them absolute authority over the administration of resources and control over commercial and domestic output. Moreover, high-ranking military members also replaced civilian factory managers which further reinforced their hegemony over public affairs.

Muhammad Anwar el-Sadat (1970 - 1981)

When Sadat took office as the president, he began to demilitarize the country by removing army officers from their positions in the government. His rule loosened the military's grip over the economy, as he diverted their focus towards defence-related manufacturing to prepare Egypt for a war with Israel. Concerned about Israel's growing military hegemony in the Middle-East and 
North Africa (MENA) region, Sadat prioritised war over the developmental reforms to pursue the Pan-Arab dream and to protect the region from Israeli expansionism.

However, in 1978, Sadat and Israeli Prime Minister Menachem Begin, developed a framework for peace between Egypt and Israel under the auspices of the former U.S. President Jimmy Carter. Historically known as the Camp David Accords, which led to the signing of a peace treaty in 1979 which ensured peace and prosperity between the two rival nations. Although it brought peace to the country, Egypt's relationship with the other Arab countries strained significantly. Nevertheless, supported by its Western allies, Sadat attained peaceful negotiations over the Sinai Peninsula (Ahmed, 2017). This treaty further strengthened Egypt's relationship with the U.S., leading to the attainment of annual defence and economic aid worth billions of dollars.

Moreover, from 1979-1997, Egypt received an annual military aid of US\$1.3 billion, which further strengthened and modernized Egypt's military (Honing, 2000). Similarly, the treaty cemented the power of the military as the front face of the republic. Influenced by the negotiations with the Western powers, he also began economic liberalization as a necessary precursor for Egypt's economic development. Numerous state-owned entities were privatised as a result of the new economic direction. Thus, although the Sadat era marked a paradigm shift in Egypt's from Nasser's socialist era, the military retained its position as the most powerful institution in the country.

Hosni Mubarak (1981-2011)

After Sadat was assassinated 1981, Hosni Mubarak, former's senior aide, ascended to the presidential throne. He ruled Egypt with an iron fist, unbent from a number of agitations and antigovernment riots during his reign. Under him, between 1999 and 2010, the GDP grew at an annual average rate of $5 \%$, but at the same time, Egypt was faced with spiking disparity in the country's economic development, with lack of opportunities for the general public (Ahmed, 2017). Still, however, the military protected Mubarak's regime from securing the status quo. In the turbulent times of 2011, leading to the uprisings, Egypt was engulfed by corruption and myriad problems that overwhelmed Cairo. Widely attributed as a kleptocratic state, Hosni Mubarak's government, with a garrison state structure benefited the few Egyptians elite, at the expense of many povertystricken Egyptians. Moreover, unemployment increased, and wages dropped as a result of decreased public investment (Transparency International, 2018).

A perpetual state of emergency was implemented in Egypt because of the enactment law 
1958/64, declared by President Mubarak. This law gave the president an authority to restrict the freedom of assembly, movement, and arrest suspects dangerous to public security at any time. He also established an economic arm cell called the National Service Products Organization (NSPO) responsible for creating cheap goods for lower and middle classes by contributing to the public infrastructure. Under him, the Defence Minister Abu Ghazala succeeded to generate maximum profits through military-owned projects. The roles of the military expanded to various areas. The National Service Products (NSPO), The Ministry of Military Production (MOMP), and the Arab Organisation for Industrialisation were the three primary military bodies working for nonmilitary manufacturing and services (Magd, 2013).

The tension aggravated as the military came face to face with the private sector. The military established new factories, companies, cultivated vast farms and privatized the public sector. Retired army officers began to hog administrative positions in the bureaucracy, and their profitable military businesses flourished. Finding jobs and generating income for families became a challenge for many. The IMF also projected a double-digit unemployment rate in 20122013 for Egypt.

In 2011, however, unprecedented mass demonstrations were carried out that led to the fall of a 30-year rule of Mubarak. Mubarak's overthrow was ironically supported and made possible by the same military that protected him earlier (Darwisheh, 2019). When the uprising in Tahrir Square erupted, several military soldiers joined mass demonstrations enchanting "Mubarak leave", and the protestors became convinced that the military would work towards democracy (Martini \& Taylor, 2011). In fact, after the ousting of Mubarak, the Supreme Council of the Armed Forces (SCAF), the current ruling military body, pledged to "ensure a peaceful transition of authority within a free and democratic system that allows an elected civilian authority to take charge of governing the country" (Martini \& Taylor, 2011). However, soon attempts were made by the SCAF to curb the democratic process, which made people question their true intentions.

After the fall of Mubarak, the military made use of the opportunity to assert its authority; the military was able to re-establish its relationship with the presidency, and it prevented the succession of Mubarak's son, Gamal (Darwisheh, 2019). The SCAF made itself responsible to oversee the task of transition for an initial period of six months which, according to their own rules, was later extended to 18 months that subsequently allowed them to expand their own powers. The National Democratic Party was also dissolved under the orders of the Supreme Administrative Court (SAC) (Martini \& Taylor, 2011). Such directives eventually allowed the 
military to sustain their control over political decision-making, truly cementing is hegemony in the civilian arrangements.

As Darwisheh (2019) notes, the "The SCAF temporarily sided with the January 2011 'Revolution', and took over executive authority from the presidency in the name of protecting and leading the revolution." (p.4). In other words, in order to preserve its interests and status-quo, they supported this revolution only to lay a ground that would allow them to take over civilian politics. And, unsurprisingly, Egypt only saw a brief transition to a quasi-democratic setup after Mubarak.

\section{Mohammad Morsi (2012-2013)}

The 2011 revolution was widely supported by Egypt's right-wing political party, the Muslim Brotherhood. The party rose to prominence in Egypt's political sphere after it renounced violence during Sadat's presidency. After his assassination in October 1981, the party was banned by Mubarak's successor regime. However, in 1984 party candidates independently participated in the parliamentary elections, allying with Wafd Party, and won 65 out of 450 parliamentary seats. In the later years, the candidates sponsored by the Muslim Brotherhood won even more seats forming the largest opposition bloc against the military dictatorship.

Similarly, the Muslim Brotherhood's subsidiary Freedom and Justice Party (FPJ) bagged a decisive victory in the parliamentary elections held after the ouster of Mubarak in February 2011. The elections were held under the auspices of the SCAF-led transitionary government. FPJ won around $47 \%$ of the parliamentary seats, and their victory paved way for its chairman, Mohamed Morsi, to run for the presidency against Mubarak's former aide, Ahmed Shafik. However, afraid of an overwhelming majority of anti-military Islamists, the Supreme Constitutional Court - Egypt's top judicial body dominated by Mubarak's appointed judges - dissolved the parliament just two days before the presidential elections (Kirkpatrick, 2012). Even though the decision did not elicit a direct response from the SACF, it was widely favoured by the so-called progressive sections close to the military establishment (Kirkpatrick, 2012). Nevertheless, FPJ's presidential candidate won the presidential elections with around $51 \%$ of the overall votes (Aljazeera, 2012).

Although regarded as the first step towards democracy in the history of Egypt, the Muslim Brotherhood was opposed by the bureaucracy, army, the interior ministry, and the judiciary (AlAnani, 2015). Even before their election, the members of the Muslim Brotherhood were apprehended, denied to assume ministerial positions, and were largely treated as pariahs. This can be sensed in the words of a Brotherhood leader who underlines: "We were always treated as 
second-class citizens under Mubarak. If you were a member of the Muslim Brotherhood, you will not join the army, become a minister or a governor" (Al-Anani, 2015). Thus, even during their rule, despite being the largest social movement in Egypt, their attempt to control the state institutions such as the ministries of the interior, defence, foreign affairs was met with resistance. The Muslim Brotherhood had minimal control over the ministries it held (Al-Anani, 2015).

Nonetheless, to exert itself against the military and judicial establishment, Morsi issued a presidential decree that granted him powers to avoid the court's oversight, and the Muslim Brotherhood started to intervene in mega projects such as the Suez Canal, which threatened EAF's monetary interests. It is argued that the Suez Canal became the main point of confrontation between the ruling party and the military. According to the global human rights watchdog "The Brotherhood was going to consolidate its economic position through the canal area ...This would have stripped the military of its control of the biggest development project Egypt will have over the coming two decades" (Transparency International, 2018).

Moreover, with its rise premised on the conservative doctrine of promoting "Islamic" values, FPJ and Muslim Brotherhood was widely opposed by the moderate and progressive sections of the Egyptian civil society. Benefitting from the ideological cleavages among the Egyptians, the SCAF retained its control over state's political affairs, often as a mediator between the pro and antiMorsi blocs. This meant that President Morsi inherited a quasi-autonomous presidency with less to no real power to reform Egypt's centralized-military-dominated structure. Thus, finally in April 2013, a movement against Morsi, anti-Morsi Tamarrud (rebellion), erupted to topple his government and manifested into massive street protests till the end of June. Soon after, head of the EAF and defence minister, General Abdel Fatah el-Sisi announced the suspension of the constitution, ostensibly, to protect Egypt enveloped by civil unrest. Following the coup d'état, several protestors were arrested and 529 detained supporters of the Muslim Brotherhood were issued a death sentence over a single verdict in 2014 (Transparency International, 2018). Ketchley (2017) argues that Egypt's security forces created conditions for Morsi's removal and instrumentalised anti-Morsi campaigns to destabilize democracy for staging a coup.

Abdel Fattah el-Sisi (2014-Present)

Currently, President Abdel Fattah el-Sisi stands as the head of the military junta, who came to power after toppling a short-lived democratically elected government in a bloody coup d'état (Kosak, 2016). His armed forces are known for pursuing strategies that grant them extraordinary power and privileges. For example, they have passed legislation "to continue to grant itself ever- 
expanding rights and continue to position military officers in senior government positions (Transparency International, 2018).

According to Article 204 of the Constitution, members of the military and intelligence services are immune from any civilian oversight (Transparency International, 2018). Moreover, Al-Sisi's government continues to curtail voices of journalists, media, bloggers, and protestors, and civil society activists; at least 3000 civilian homes have been demolished by Egypt's army in Sinai where they are fighting ISIS; around 20 journalists have been detained; and, between August 2017 - August 2018, at least 230 cases of enforced disappearances have taken place (Human Rights Watch, 2019). Under the guise of combating terrorism, they have not only arrested political opponents, but they have also instilled fear and violence among the masses.

Under Sisi, the Egyptian military remains the most institutionalized structure of the state. It is much more than a national defence force of the state and can be regarded as the core political ruling class that continues to exert a significant influence on the country's political arena (Kosak, 2016). By occupying bureaucratic, ministerial, and presidential positions, military officers exercise direct autonomy over most areas of policymaking, especially after SCAF assumed full power in early 2011.

In the words of Bradely (2012):

In Egypt, however, it was the military that forced Mubarak out, and then a small number of generals appointed themselves as interim rulers. In other words, there occurred a military coup. Egypt moved from being a military dictatorship with a military man acting as president, to being a sole military dictatorship.

\section{Ramifications of the Garrison State for Egypt's economy}

The core macroeconomic structure of Egypt remains widely dominated by the military elite since its independence in 1952. After Gamal Abdel Nasser came to power through the Free Officers Movement, he initiated numerous nationalisation reforms virtually spearheading Egypt's crippling economy out of the vicious trap. While doing so, he established the Ministry of Military Production in 1954, which was primarily responsible for fulfilling the republic's defence needs amidst rising hostility in the MENA region. The industry not only supported the country's defence 
but also stimulated the country's aggregate production to some extent. In 1961, however, Nasser appointed the defence minister General Abder Hakim Amer to head the Higher Council for Public Enterprises of an Economic Charter, unconventionally inducting the EAF in state decision making on the economic front. Since then, the military has played a major role in nearly all the state's economic policies and is widely viewed as the main actors of economic development.

Sayigh's (2019) recent incisive analysis into the economic expansion of Egypt's military provides lucid details about how the military is jeopardising sustainable economic growth in the country. Military captures a disproportionate share of public revenues and resources, notes Sayigh, which would otherwise have gone to competing state institutions and private companies, and diverts considerable amounts of investment capital from other productive sectors of the economy (Sayigh, 2019). His analysis underscores that EAF entrepreneurial ambitions are "crowding-out" Egypt's market, encroaching spaces erstwhile necessary for the competitive private-market dynamics to prevail. The military junta influences the economic policies via three basic pillars of the EAF: the Defence Industry led by the Ministry of Military Production (MOMP); Agencies and contractors that work in cahoots with the Ministry of Defence (MOD); and retired military officers turned entrepreneurs, who head leading private and public sector enterprises in Egypt (Sayigh, 2019). Through this troika that forms the "economic elite of Egypt", and reflects institutional derailment in the country, the EAF virtually controls all the economy-related decisions and policies.

Moreover, the MOD holds the unprecedented power to license the use of more than 90 percent of Egypt's total surface area (Sayigh, 2019). The entitlement provides an unparalleled military advantage over other economic players, and has been a significant source of income in the past three decades - it has been primarily utilized in expanding the military's industrial complexes, housing schemes, farms, and other projects. However, regardless of the economic entitlements, the military enjoys, the contribution of the Defence Industry remains largely domestic, with low to negligible share in the country's export.

Due to the inadequate investment in R\&D, Egypt's arms production lacks efficiency and adeptness to global standards. Lack of innovation and inability to absorb foreign technology remains the primary reason why the industry that occupies the "lion-share" in the macroeconomic structure fails to capture even a small share in the foreign export market. On the other hand, according to Stockholm International Peace Research Institute (SIPRI), Egypt's arms imports tripled between 2010-14 and 2015-19, making it the world's third-largest arms importer - a massive jump of 
nearly $206 \%$ from the preceding decade (Kuimova, 2020) - placing a big toll on the country's current account. And because of the recent devaluation of the Egyptian pound in accordance to the IMF-led adjustment program, the spike in the prices of imported goods makes the military trade even more untenable. Moreover, notwithstanding the heavy subsidies and tax exemptions the industry receives, the contribution of the defence industry is not more than 1.5 percent of Egypt's GDP, even on the domestic front (Sayigh, 2019).

As Momani highlights, military involvement in the economy, and the consequent misallocation of public investment into unproductive sectors and the defence industry, is adding a great cost to the welfare of ordinary Egyptian (Momani, 2020). Consistent with the prediction of Harold Laswell (1941), and with the findings of Abell (1994), capital flow to the poorest segments of the society is continuously shrinking in Egypt. The primary reason, Momani argues, is that the military-led public sector heavily invests in redundant infrastructure and construction projects, often led by military contractors that cater to a small upper and upper-middle-class groups, leaving behind the poorest segments of societies without basic utilities and services (Momani, 2020). Since the contractors exclusively operate under the EAF oversight, the participation of civilians remains low, with virtually no effect of unemployment. Thus, because of the garrison state structure of Egypt's economy, the poverty rate remains high, and employment among females and youth is low, reflecting massive discrepancies in opportunities for certain marginalized groups. The rise in GINI index from 28.3 to more than 31 in recent years, also captures this upward trend in rising inequality in Egypt (World Bank, 2020).

While the public sector remains largely dominated by the military junta, the case of the private sector is not so different. Companies led by the officer class receive lucrative exemptions from tax and levies from the government. For example, enterprises affiliated with the EAF are exempted from Value-added Tax (VAT) and import taxes, placing a toll on the non-affiliated sector, which fulfils this gap by paying extra taxes. Similarly, retired military officers and scions of military elites hold important positions in leading private enterprises in Egypt, and many have also started their own ventures to penetrate the private sector. Gamal Mubarak, the son of former president Hosni Mubarak, for example, is a leading businessman in Egypt who holds a number of stakes and equities in Egypt's top investment bank - EFG Hermes. As noted by a report from the Carnegie Middle East Center:

By the time Sisi came to power in 2013, the Egyptian armed forces owned companies in almost every sector in the domestic economy... the Egyptian military-owned manufacturing facilities to produce cement, 
steel, vehicles (passenger cars, subway cars, rail wagons, and tractors), agrochemicals (especially fertilizers), and energy (petroleum retail); it also provided services in public construction (including desalination plants), mining, logistics, and retail. In addition, it owned factories manufacturing pharmaceuticals, processed and refined foods, home appliances, kitchenware, computers, and optical equipment. It reclaimed hundreds of thousands of acres of desert land and constructed bridges, hotels with lucrative special event venues, seaside resorts with luxury summerhouses, apartment buildings, and lavish villas. It ran gas stations, shipping firms, domestic cleaning companies, and parking lots (Zeinab, Akça, \& Marshall, 2020).

This also explains why Egypt ranks way lower, at 114, in the Ease of Doing Business Index, than its peer economies like Saudi Arabia (62), Oman (68), Jordan (75), and Tunisia (78) (The World Bank, 2020).

Lastly, it is important to underline that although Egypt's cumulative expenditure on defence continues to decrease in inflation-adjusted terms, and is, in fact, one of the lowest in the MENA region, it does not capture the true dynamics of military spending. According to the report by SIPRI, many non-combative expenditures of EAF are not accounted for in the official figures. This includes spending on arms procurement and internal security spending under the Ministry of Interior (MOI). The report estimates the internal defence expenditure to be about $\$ 833$ Million - 14 Billion Egyptian pounds (Kuimova, 2020). The report from the global military watchdog also underscores that because of lack of transparency in Egypt's military budgeting and its arms procurement, it is difficult to identify the actual sources of funding for its arms deals (Kuimova, 2020). Indicating a possibility of covert deals that are never registered in the official data. Thus, claims of lowering military expenditures, often touted by the government officials, should be considered with a grain of salt.

Deterioration of socio-economic factors under military rule

The politics of social factors, i.e., healthcare, education, income equality (HDI), gender equality, and so on, is a multifaceted topic, which requires a theoretical framework. According to Amartya Sen's schema of 'Development as Freedom' socio-economic freedoms are as important to development as macroeconomic growth. Sen (1999) categorizes five types of freedoms which reinforce and interact with each other; "economic empowerment, political freedoms, social 
opportunities, protective security, and transparency" (Sen, 2006, p.161). Each of these freedoms is essential to provide capabilities to the population, required for overcoming structural poverty and inequality.

Moreover, according to Sen, poverty is not only a result of low income, but it is also a result of deprivation of education, adequate health facilities, equal opportunities, and a safe and inclusive environment. As we highlight in the following sections, inadequate facilities in these arenas have caused numerous structural issues in Egypt's economy. This has not only resulted in the low level of productivity in the population (Morsy et al., 2014) but has also instilled discontent for the governing body - leading to frequent instances of anti-government demonstrations and rise in militarism.

As the military elite strives to consolidate Egypt's centralised garrison state structure, it continues to deprive the masses of basic needs. This section, therefore, highlights the consequences of Egypt's garrison state on its socio-economic factor. To provide a dynamic picture of the problematic state of Egypt's civil structure, we have divided this section into three aspects which are crucial for development: health, education, and gender equality. Moreover, before jumping to our analysis, it is imperative to underline that simply relying on Egypt's Human Development Index (HDI), which records a value of nearly 0.700 (UNDP, 2019), can be grossly misleading. In fact, the HDI value slips down 29.7 percentage points (0.492) when adjusted for inequality in the country (UNDP, 2019).

Healthcare

Egypt's health sector crisis has existed for several decades. The neglected public hospitals, rampant corruption, lack of accountability, inadequate health insurance system, poor-quality, unaffordable, and unreliable public healthcare has resulted in a calamity for various Egyptians. In 2013, amongst the 193 member states of the WHO, Egypt was ranked 118th in terms of life expectancy at birth (WHO, 2016). In the fiscal year 2015-2016, 5.4 percent of the total government budget was allocated to the healthcare system as compared to 12 percent allotted to the education sector (Egypt's State Budget, 2016). One plausible explanation behind this crisis is military domination. Military dominance in Egypt has been sturdy enough to impact the county's development overall, and the healthcare system remains one of these social factors that has been influenced by its ascendency.

The 2011 revolution was divided into different aspects: on one hand, reforms were demanded for 
the betterment of citizens' rights in Egypt. On the other hand, there was an uprising in which doctors rebelled against the state. Many of the doctors who volunteered in the field hospitals since January 2011 appealed to an ethos of medical neutrality, by which they meant their abidance by the principle of medical impartiality, which impels medical personnel to provide care without discrimination to all those who need it (Hamdy \& Bayoumi, 2015). They demanded that the civil-military dichotomy be abolished in Egypt, so that everyone, regardless of their institutional association, can receive equal medical aid. However, their demands did not settle well with the state dominated by the military's interest. Under the command of former general Abdel Fattah el-Sisi (now the president of the republic), police forces embattled the field hospitals as various field hospitals were constantly beleaguered with teargas canisters, and numerous doctors were injured or detained (The Egyptian Initiative for Personal Rights, 2011).

Apart from that, the healthcare system largely suffers from inefficient management due to the centralized control by the military-led central government (Elden, Rizk \& Wahby, 2016). Even though the health budget was increased, and the Health Sector Reform Program (HSRP) was launched, the system still remains incompetent, while the government's focus on the pharmaceutical sector has amplified. Simultaneously, the Egyptian government also gave the military a license to establish pharmaceutical companies in the country. Similarly, the Sisi administration has massively subsidized the pharmaceutical industry. Although it helped in marginally lowering the shortage of drugs in Egypt, the subsidization has also helped the militaryled pharmaceutical industries in generating more profits (Farid, 2017).

On the other hand, the EAF has separate highly maintained medical services in order to assist the armed forces personnel and their families. For EAF, the Medical Services Department of the Armed Forces and the Egyptian Army Medical Corps are the two departments that are responsible for hospitals and other medical facilities, including the Army medical schools. Although these hospitals also cater to the civilians, they are usually expensive while they operate free of cost for the military officers and their families. Currently, the Medical Services Department operates about 48 fixed military hospitals while The Army's Medical Corps handles 100+ Field Medical Companies (Armed Forces College of Medicine, n.d.). Even though these hospitals can be deemed as a necessity, their operation requires funding which is either diverted away from the public sector hospitals or is provided through an increment in the military budget, which in turn reduces the allocated budget for other economic sectors, reflecting massive inequality in the country's health structure. 


\section{Education}

Education is one of the key factors for development and sustainable economic growth. Good quality of education can potentially reduce poverty and inequality, improve public health, and foster civic engagement (UNESCO, 2009). However, like the health sector, education remains largely neglected in Egypt because of its garrison-state economic structure.

Historically, the ruling military elite in Egypt maintained its political and economic privileges by curtailing the public from exercising their democratic power against the state. Therefore, to maintain its hegemony, the military elite used education as a tool to direct public discourse according to its own needs. Under Nasser, for instance, education did expand; however, he did not permit the development of modern teaching methods, and the traditional education system was prioritized. Traditional methods, like rote learning, remained prevalent in an attempt to imitate the Western style of education. However, it debarred the students from acquiring the necessary skills required for critical thinking and innovation. Dr Al Abd described this dilemma as a 'Diploma Disease', which attributes to the creation of 'certified' professionals who are out of touch with the real needs of the society (Dore, 1976).

When Sadat took over in 1970, he pledged to revolutionise the education system but failed to do so as he continued Nasser's unsuccessful policies. Despite the influx of foreign aid into the educational system, the state did not have sufficient money to maintain the services established after the 1952 revolution. Although half of the population was officially educated by the early 1980s, about one quarter lacked formal credentials (Brown, 2011). Such credentials, while not necessary to find gainful employment, were necessary to lose the stigmatism of illiteracy. Moreover, despite Sadat's acknowledgement that education reform was long overdue (Sadat, 1974), education was not prioritized among the state projects authorized under the 1974 foreign investment law - Law 43 (Brown, 2011).

Similarly, Mubarak's regime advocated reforming the public sector and elevating the lives of Egyptians; however, most of such reforms remained self-serving. While the literacy rate in improved under his rule, and the enrolment in the primary schools increased, there were still significant levels of inequality based on class difference, rural-urban divide, and gender discrimination. Many issues of safety, location, overcrowding, and so on largely remained unaddressed under Mubarak's longest tenure, and the education gap grew with the increasing gap between the rich and poor. The elite secured better employment opportunities due to the high quality of education, while the poor were further marginalised (World Bank, 2007). 
President Sisi declared 2019 as the 'Year of Education', thereby launching a National Project to reform the education system. However, the percentage of the total state revenue allocated to education is negligible, which suggests that the government is not equipped with the fiscal capacity to enact such reforms.

In the past decade, Egypt has received billions of dollars for external investment and megaprojects, but only two initiatives have focused on education, and the first of those failed to achieve its goals (Johnson, 2018). In addition to that, the issues of outdated facilities, conventional teaching methods, overcrowded classes, and educators not teaching because of unpaid or low salaries remain persistent. Consequently, Abou-Zeid (2016) indicates that there was a substantial increase in unemployment for degree holders and high school graduates (Zied, 2016).

On the other hand, the military regimes established institutions catering to the military elites while the systematic inequalities restricted the poor students from acquiring quality education. As per the state provisions, the education is free; however, the inefficiency and inadequacy of public education make additional tuition by private tutors essential, which is only affordable by the country's elites. In the same context, Fahim and Sami (2011) also identified that access to higher education is biased against the poor in Egypt because of their socio-economic status (Amira, 2017). For example, being a military or police officer guarantees welfare and prestige that is supported by the government. Hence, the elites have sufficient finances to spend on private tutoring, which helps them secure better grades and admission to renowned universities, while the general population is deprived of such opportunities.

The historical transition of Egypt under the military regimes underlines that the state used education as a tool to prepare an officer class composed of the military and bureaucratic elite to govern the masses, while depriving the latter of equal opportunities - an arrangement Hamza Alavi dubs as an "overdeveloped state" of officers, which reflects perpetual class inequality (Alavi, 1972). Similarly, religious education was often prioritized, reinforcing a unified code of behaviour that promotes social control (Brown, 2011). Hence, the blend of Pan-Arab nationalism under Nasser, Islamic Traditionalism and Euromerican policies under Sadat, Mubarak and el-Sisi perpetuated an authoritarian system in which progressive and democratic ideas had no relevance. According to the UNICEF (2004), social change can occur only if the politics of education mandates increased quality, not just quantity. However, such education is not accessible to many Egyptians. There are numerous worrisome trends which assert the lack of 
quality of education is one of the causes of the increasing inequality and poverty in Egypt and other military-dominated Arab nations. A World Bank report of 2008 recorded that despite constitutional guarantees for universal access to education, Arab States still have relatively low net enrolment rates and high illiteracy rates (Zaher, 2010).

Finally, the expansion of education under Egypt's garrison state largely served the purpose of exacerbating class inequality in the country - creating two different classes: the bourgeois composed of the civil-military elite and the proletarians largely constituted by the general population., and even the recent regimes of Mubarak and Sisi, with a largely liberal, progressive and secular outlook, did not make any significant effort to improve the standards of education regardless of the fact that they received generous foreign aid from donor countries for this cause.

\section{Gender inequality}

Gender equality is often an indicator of democratic freedom in a country. Not only does it help distinguish democratic countries from totalitarian and despotic regimes, but it also shows how equal societies are in terms of social opportunities. Garrison and military-dominated states usually discriminate against women because of the patriarchal structure of modern militaries, and Egypt is no exception. "Women are constantly subjected to violence in the form of sexual harassment and abuse on the street, and approximately ninety-seven percent of Egyptian women are the victims of female genital mutilation" (The Egyptian Centre for Women's Right, 2020, p.01). In Egypt, women do not only suffer at the hands of their families but are also oppressed by the agents of the military-led state who are often involved in women rights violations.

Laws against the oppression of women do exist in Egypt, but the state has largely failed to enforce them. Egypt's law enforcement agencies repeatedly use women as pawns against their suspected male relatives. After the terrorist attack in 0ctober 2004, such an incident came to notice on the Red Sea Coast when police, along with the state security agents arrested hundreds of people living in nearby towns. However, for the people they failed to trace, they apprehended their female relatives and subjected them to torture, harassment, public humiliation, detention, and sexual and physical abuse. Another such case unfolded when a woman was subjected to physical and sexual abuse during the May 25, 2005 referendum vote, by security officials (The Egyptian Centre for Women's Right, 2020). Although police are classified as a different institution, it falls under the Ministry of Interior (MOI), which is heavily influenced by the military elite. These occurrences prove that armed forces, which ironically exist to protect the residents of Egypt, deliberately oppress women exacerbating gender inequality in the country. 
Moreover, women's involvement in the military has been historically low since the inception of Egypt's republic. Even though, currently, campaigns are being run by NGOs to establish a gender balance in the military; however, these demands are often met with sarcasm from people who consider women as fragile objects. They claim that women will be unable to handle the burdensome military service, leading to severe physical challenges for them. (Egyptian Streets, 2017).

Lastly, regardless of the fact that the military elite maintains a facade of progressivism, women are deemed "not strong enough", and are denied spaces in the armed forces. Similarly, their representation in politics dominated by the military has only marginally increased, and largely remains lower than competitive economies like Turkey and Tunisia (UN Women, 2019). This further leads to discrimination because the extremely low representation of women in politics paves the way for oppressive patriarchal laws, which further leads to the violation of women rights (Jamilah \& Machmudi, 2019).

\section{Conclusion}

In our final note, we conclude that Egypt's case of underdevelopment can be attributed to hegemonic monopoly of the military which plays a critical role in its economic decline as exposited through Laswell's Garrison theory and Sen's schema of development as freedom. Through this study we demonstrated how Egypt's garrison states roots, which go back to the first centralized government under Nasser, have massively curtailed political and socio-economic freedom of Egyptians by exacerbating structural inequality in different sectors of the economy.

Furthermore, the study underlined that under such circumstances a level playing field between military-sponsored entities and private entrepreneurs is missing, which is jeopardizing the inflow of investment from private firms, putting immense pressure on the country's macroeconomic structure. Similarly, the underfunded and unequal social sector, because of military domination, is further pushing Egypt into a vicious and perpetual underdevelopment trap.

Therefore, to embrace the path of sustainable economic development which can ameliorate ordinary Egyptians out of the plight of poverty and underdevelopment, instead of catering to a small elite, it is important to allow diversification and democratization of Egyptian political structure. If, on the other hand, Egypt continues to embark on the trajectory it is currently headed on, rising disparities and economic inequality can exacerbate public dissent, unleashing civil unrest in an already volatile country. 


\section{References}

Abell, J. D. (1994). Military spending and income inequality. Journal of Peace Research, 31(1), pp.35-43.

Abou-Zeid, M. (2016). Academic integrity: a perspective from Egypt. In T. Bretag (ed.), Handbook of academic integrity (1st ed., pp. 135-145). Singapore: Springer.

Ahmed, A. (2017). Back to square one: understanding the role of the Egyptian armed forces. City University of New York (CUNY).

Al-Anani, K. (2015). Upended path: The rise and fall of Egypt's Muslim Brotherhood. The Middle East Journal, 69(4), 527-543.

Al Jazeera. (2012). Celebration in Egypt as Morsi declared winner. Retrieved January 12, 2021, from: https://www.aljazeera.com/news/2012/6/24/celebration-in-egypt-as-morsi-declaredwinner

Alavi, H. (1972). The state in post-colonial societies Pakistan and Bangladesh. New Left Review, 74,59 .

Amira, M. (2017). Higher education and development in Egypt. The African Symposium Journal, $16(1), 63-73$.

Armed forces College of medicine. (n.d.). Retrieved on November 22, 2021, from: http://www.afcm.edu.eg/EN/

Birchler, K. (2012). The effect of military political power on economic development in dejure democracies. Universität Zürich, Department of Political Science. Zurich: Center for Comparative and International Studies (ETH Zurich and University of Zurich).

Bradley, J. (2012). After the Arab spring. New York City: Palgrave Macmillan.

Brown, H. K. (2011). Education reform in Egypt: reinforcement \& resistance. Northeastern University, Boston, MA. 
Buzan, B., \& Sen, G. (1990). The impact of military research and development priorities on the evolution of the civil economy in capitalist states. Review of International Studies, 16(4), 321339 .

Collier, P. (2006). War and military expenditure in developing. The Economics of Peace and Security Journal, 1(1), 10-13.

Darwisheh, H. (2019). Egypt under Sisi: from an authoritarian dominant party system to strongman politics. JETRO-IDE ME-Review, 6, 1-20.

Deger, S., \& Smith , R. (1983). Military Expenditure and Growth in Less Developed Countries. The Journal of Conflict Resolution, 27(2), 335-353.

Dore, R. (1976). The Diploma disease. California: University of California Press.

Egypt's State Budget [Arabic]. Retrieved January 15, 2016 , from http://www.budget.gov.eg/Budget20142015/Budget/2ca0bea2-0bc8-453f-adb7cb1de74ce781

Egyptian Streets. (2017). Women in Egypt's army: A demand aiming for equality usually met with sexism. Retrieved November 22, 2020, from https://egyptianstreets.com/2017/08/01/womenin-egypts-army-a-demand-aiming-for-equality-usually-met-with-sexism/

Elden, N., Rizk, H., \& Wahby, G. (2016). Improving health system in Egypt: perspectives of physicians. The Egyptian Journal of Community Medicine, 31(1), 45-58.

Fahim, Y., \& Sami, N. (2011). Adequacy, efficiency and equity of higher education financing: The case of Egypt. Prospects, 41, 47-67

Farid, S. (2017). Why is Egypt's military entering the pharmaceutical industry? Retrieved November 22, 2020, from: https://english.alarabiya.net/en/features/2017/02/02/Why-is-Egypts-military-entering-the-pharmaceutical-industry-

Hamdy, S., \& Bayoumi, S. (2015). Egypt's popular uprising and the stakes of medical neutrality. Culture, Medicine, And Psychiatry, 40(2), 223-241. 
Honing, D. (2000). A mighty arsenal. Retrieved November 30 2020, from https://www.washingtoninstitute.org/policy-analysis/view/a-mighty-arsenal-egypts-militarybuild-up-19791999

Human Rights Watch (2019). World Report 2019: Rights trends in Egypt. Retrieved November 25, 2020, from: https://www.hrw.org/world-report/2019/country-chapters/egypt

Ibrahim, S. E. (1995). Civil society and prospects of democratization in the Arab World. Civil Society in the Middle East, 1, 27-54.

Jamilah, M. \& Machmudi, Y. (2019). Political gender inequality in Egypt after the Arab Spring (2011-2013). In 2nd International Conference on Strategic and Global Studies (ICSGS 2018) (pp. 186-192). Atlantis Press.

Johnson, D. (2018). Egypt's long road to education reform. Retrieved November 30 2020, from: https://timep.org/commentary/analysis/egypts-long-road-to-education-reform/

Ketchley, N. (2017). Analysis | How Egypt's generals used street protests to stage a coup. Retrieved January 12, 2021, from https://www.washingtonpost.com/news/monkeycage/wp/2017/07/03/how-egypts-generals-used-street-protests-to-stage-a-coup/

Kirkpatrick, D. D. (2012). Blow to transition as court dissolves Egypt's parliament. The New York Times. Retrieved January $12,2021, \quad f r o m$ https://www.nytimes.com/2012/06/15/world/middleeast/new-political-showdown-in-egypt-ascourt-invalidates-parliament.html

Koşak, Ç. (2016). How does the military dominate Egyptian politics? Unpublished doctoral dissertation, İstanbul Şehir University. Graduate School of Humanities and Social Sciences.

Kuimova, A. (2020). Understanding Egyptian military expenditure. Stockholm International Peace Research Institute. Retrieved January 122021 , from https://www.sipri.org/sites/default/files/202010/bp_2010_egyptian_military_spending_2.pdf Laswell, H. (1941). The Garrison State. American Journal of Sociology, 46, 455-468. 
World Health Organization (WHO). (2016). Life expectancy at birth, 1990-2013. Retrieved January 15,2016. http://gamapserver.who.int/gho/interactive_charts/mbd/life_expectancy/atlas.html.

Magd, Z. A. (2013). The Egyptian military in politics and the economy: recent history and current transition status. CMI Insight.

Martini, J., \& Taylor, J. (2011). Commanding democracy in Egypt: The military's attempt to manage the future. Foreign Affairs, 90, 127.

Momani, B. (2020). The chronic underperformance of Egypt's military economy. Carnegie Middle East Center, 0ctober 26 . Retrieved 25 January, 2021 , from https://carnegiemec.org/2020/10/26/chronic-underperformance-of-egypt-s-military-economypub-83013

Morsy, H., Levey, A. \& Sanchez, C. (2014). Growing without changing: a tale of Egypt's weak productivity growth. London: European Bank for Reconstruction and Development.

Sadat, A. (1974). The October working paper. Cairo: Arab Republic of Egypt, Ministry of Information, State Information Service.

Sayigh, Y. (2019). Owners of the Republic: an anatomy of Egypt's military economy. Carnegie Middle East Center. Beirut: Carnegie Endowment for International Peace.

Sen, A. (1999). Development as freedom. Oxford: Oxford University Press.

The Egyptian Center for Women's Rights. (2020). Violence against women in Egypt. Retrieved $\mathrm{J}$ a n u a r $\quad 20, \quad 2021, \quad \mathrm{fr} 0 \mathrm{~m}$ https://www.un.org/womenwatch/daw/vaw/ngocontribute/Egyptian\%20Center\%20for\%20Wo men_s\%20Rights.pdf

The Egyptian Initiative for Personal Rights. (2011). Field doctors bear witness to the targeting of field hospitals in Tahrir Square by security forces and military police. Retrieved February 8, 2016, from, https://eipr.org/en/press/2011/12/egyptian-initiative-personal-rights-field-doctors-bearwitness-targeting-field 
The World Bank (2007). Arab Republic of Egypt: Improving quality, equality, and efficiency in the education sector. Education Sector Policy Note, Cairo.

The World Bank. (2020). Doing business 2020: comparing business regulation in 190 economies. Washington DC: International Bank for Reconstruction and Development - The World Bank.

The World Bank. (2020). Gini index (World Bank estimate) - Egypt, Arab Rep. Retrieved from The World Bank: https://data.worldbank.org/indicator/SI.POV.GINI?locations=EG

Transparency International. (2018). The officers' republic: the Egyptian military and abuse of power. United Kingdom: Transparency International.

The United Nations Educational, Scientific and Cultural Organization (UNESCO). (2004). Education for all: The quality imperative (EFA global monitoring report). Paris: UNESCO.

The United Nations Educational, Scientific and Cultural Organization (UNESCO). (2009). Overcoming inequality: why governance matters (EFA global monitoring report). Paris: UNESCO. The United Nations Development Programme (UNDP) (2020). Human development report. New York:UNDP.

UN Women. (2019). Women in politics: 2019. https://www.unwomen.org/en/digitallibrary/publications/2019/03/women-in-politics-2019-map

Zaher, S. (2010). The human right to education in Arab countries: an international law perspective. In A. E. Mazawi \& R. G. Sultana (eds.), Education and the Arab world: political projects, struggles and geometries of power (pp.181-195). New York: Routledge.

Zeinab, A.M., Akça, I.., \& Marshall, S. (2020). Two paths to dominance: military businesses in Turkey and Egypt. Washington DC: Carnegie Endowment for International Peace. 